\title{
The Activation of Dopamine D4 Receptors Inhibits Oxidative Stress-Induced Nerve Cell Death
}

\author{
Kumiko Ishige, Qi Chen, Yutaka Sagara, and David Schubert \\ Cellular Neurobiology Laboratory, The Salk Institute for Biological Studies, La Jolla, California 92037
}

Oxidative stress is thought to be the cause of nerve cell death in many CNS pathologies, including ischemia, trauma, and neurodegenerative disease. Glutamate kills nerve cells that lack ionotropic glutamate receptors via the inhibition of the cystineglutamate antiporter $\mathrm{x}_{\mathrm{c}}^{-}$, resulting in the inhibition of cystine uptake, the loss of glutathione, and the initiation of an oxidative stress cell death pathway. A number of catecholamines were found to block this pathway. Specifically, dopamine and related ligands inhibit glutamate-induced cell death in both clonal nerve cell lines and rat cortical neurons. The protective effects of dopamine, apomorphine, and apocodeine, but not epinephrine and norepinephrine, are antagonized by dopamine D4 antagonists. A dopamine D4 agonist also protects, and this protective effect is inhibited by U101958, a dopamine D4 an- tagonist. Although the protective effects of some of the catecholamines are correlated with their antioxidant activities, there is no correlation between the protective and antioxidant activities of several other ligands. Normally, glutamate causes an increase in reactive oxygen species (ROS) and intracellular $\mathrm{Ca}^{2+}$. Apomorphine partially inhibits glutamate-induced ROS production and blocks the opening of cGMP-operated $\mathrm{Ca}^{2+}$ channels that lead to $\mathrm{Ca}^{2+}$ elevation in the late part of the cell death pathway. These data suggest that the protective effects of apomorphine on oxidative stress-induced cell death are, at least in part, mediated by dopamine D4 receptors via the regulation of cGMP-operated $\mathrm{Ca}^{2+}$ channels.

Key words: HT22 cells; cell death; apomorphine; apocodeine; dopamine D4 receptors; glutamate; cGMP
Dopamine and its five receptor subtypes play diverse roles in the CNS. Their activation is thought to adversely contribute to several neuropathological disorders, including Parkinson's disease and schizophrenia (Seeman and Van Tol, 1994; Sokoloff and Schwartz, 1995). In addition, dopamine may have a neuroprotective role. Catecholamines, such as dopamine, norepinephrine, and epinephrine, are thought to protect nerve cells at low doses by virtue of their antioxidant activities, but are neurotoxic at high doses, acting as pro-oxidants (Noh et al., 1999). It has also been reported that dopamine receptor agonists have neuroprotective effects that are caused by nonreceptor-mediated mechanisms. For example, bromocriptine and apomorphine act as free radical scavengers (Yoshikawa et al., 1994; Sam and Verbeke, 1995; Grünblatt et al., 1999). In addition, dopamine D3 receptors are not critical for the neuroprotection by the D3 agonist, pramipexole, in 3-acetyl pyridine-treated rats (Sethy et al., 1997). In contrast, some recent reports suggest receptor-mediated mechanisms for protection by dopamine receptor agonists. For example, bromocriptine protects dopaminergic neurons from levodopa-induced toxicity by stimulating dopamine D2 receptors (Takashima et al., 1999).

HT22 cells are immortalized mouse hippocampal cells and can be considered a model of oxidative toxicity on exposure to glutamate. HT22 cells have no ionotropic glutamate receptors (Ma-

\footnotetext{
Received April 23, 2001; revised April 23, 2001; accepted May 31, 2001.

This work was supported by a Nihon University grant to K.I., the Bundy Foundation Fellowship to Q.C., and grants from the United States Department of Defense (DAMD 17-991-1-9562) and the National Institutes of Health to D.S. We thank Drs. Pamela Maher, Richard Dargusch, and Shirlee Tan for their comments on this manuscript.

Correspondence should be addressed to Dr. David Schubert, The Salk Institute for Biological Studies, 10010 North Torrey Pines Road, La Jolla, CA 92037. E-mail: schubert@salk.edu.

Copyright (ㄷ) 2001 Society for Neuroscience $\quad 0270-6474 / 01 / 216069-08 \$ 15.00 / 0$
}

her and Davis, 1996), but exogenous glutamate blocks cystine uptake into the cells via the inhibition of the glutamate-cystine antiporter, resulting in decreases in intracellular cysteine and glutathione (GSH). GSH is the major intracellular antioxidant, and its loss leads to an inability of the cell to deal with pro-oxidant conditions (oxidative stress). After GSH depletion, there is an accumulation of reactive oxygen species (ROS) and a large $\mathrm{Ca}^{2+}$ influx, resulting in a form of programmed cell death that is distinct from apoptosis (Murphy et al., 1989; Tan et al., 1998a,b; Maher and Schubert, 2000). The accumulation of intracellular $\mathrm{Ca}^{2+}$ is by $\mathrm{Ca}^{2+}$ influx through cGMP-operated $\mathrm{Ca}^{2+}$ channels (Li et al., 1997b). In this study, we examined the neuroprotective mechanisms of dopamine and related compounds on oxidative stress-induced nerve cell death in HT22 cells and primary rat cortical neurons. It is shown that the activation of D4 receptors is responsible for protection from oxidative stress by dopamine and its analogs.

\section{MATERIALS AND METHODS}

Materials. The oligonucleotides were purchased from Sigma-Genosys (The Woodlands, TX). The chemicals used were: $\left[{ }^{3} \mathrm{H}\right]$ spiperone (specific activity $610.5 \mathrm{GBq} / \mathrm{mmol}$; NEN, Boston, MA); dopamine receptor D4 affinity purified polyclonal antibody (Chemicon, Temecula, CA); 2', $7^{\prime}$ dichlorofluorescein diacetate (DCF), indo-acetoxymethylester (Indo-1), pluronic F-127, and propidium iodode (all from Molecular Probes, Eugene, OR); haloperidol and L745870 (Tocris Cookson, Ballwin, MO); and 8-(4-clorophenylthio) cGMP (pCPT-cGMP), apomorphine, apocodeine, PD168077, U101958, dopamine, and spiperone (Sigma, St. Louis, MO).

Cell culture and 3-(4,5-dimethylthiazol-2-yl)-2,5-diphenyltetrazolium bromide assay. The HT22 cells were propagated in DMEM that was supplemented with $10 \%$ fetal bovine serum (FBS). Cell survival was determined by the 3-(4,5-dimethylthiazol-2-yl)-2,5-diphenyltetrazolium bromide (MTT) assay. MTT is taken up by recycling vesicles in which it is reduced and cycled to the extracellular space (Liu et al., 1997). In the HT22 system, it is a valid measure of cell death when compared with trypan blue-based visual counting and colony formation (Maher and 
Davis, 1996). Briefly, HT22 cells were dissociated with pancreatin (Life Technologies, Gaithersburg, MD) and seeded onto 96-well microtiter plates at a density of $2 \times 10^{3}$ cells per well in $100 \mu$ l of the same medium. The next day, cells were treated with various reagents according to the experimental design. Twenty hours after the addition of glutamate, the culture medium was replaced with fresh medium because some of the catecholamines directly reduced MTT at the higher concentrations tested. In all cases, parallel dishes containing no cells were used, and for each drug concentration, cells with drug alone (no glutamate) were used to determine whether the drug had a direct interaction with the cell. These controls ensured that no direct reduction of MTT by the catecholamines occurred, and visual counts were done to confirm the MTT data. In some cases, the calcein AM viability assay (Molecular Probes) was used. For the MTT assay, $10 \mu \mathrm{l}$ of $2.5 \mathrm{mg} / \mathrm{ml}$ MTT solution was added then and incubated at $37^{\circ} \mathrm{C}$ for $4 \mathrm{hr}$, and $100 \mu \mathrm{l}$ of solubilization solution (50\% dimethylfomamide, $20 \%$ SDS, $\mathrm{pH} 4.8$ ) was added. The next day, the absorption values at $570 \mathrm{~nm}$ were measured (Liu et al., 1997). The results are shown as the percentage of the controls specified in each experiment. The primary cortical cells were prepared as described by Sagara and Schubert (1998). In all cases, cell death was confirmed by visual inspection.

Total antioxidant activity assay. Total antioxidant activity was measured using the procedure described by Miller et al., (1993) and expressed as Trolox, a water-soluble vitamin $\mathrm{E}$ analog, equivalent antioxidant capacity (TEAC). The TEAC value is the millimolar concentration of a Trolox solution having the antioxidant capacity equivalent to a $1.0 \mathrm{~mm}$ solution of sample under investigation. Briefly, $1 \mathrm{ml}$ of reaction mixture including $2.5 \mu \mathrm{M}$ metmyoglobin, $150 \mu \mathrm{M} \quad 2,2^{\prime}$-azinobis(3-ethylbenzoline 6-sulfonate), $75 \mu \mathrm{M} \mathrm{H}_{2} \mathrm{O}_{2}$, and $0.84 \%$ sample or Trolox (for standard) in PBS was incubated for $7.5 \mathrm{~min}$ at $30^{\circ} \mathrm{C}$; then the absorbance at $734 \mathrm{nM}$ was read at $7.5 \mathrm{~min}$. The data are normalized to $1 \mathrm{~mm}$ Trolox (TEAC activity).

$G S H, R O S$, and $\mathrm{Ca}^{2+}$ measurements. Total GSH was measured as described by Tan et al. (1998a), using pure reduced glutathione as the standard. ROS and $\mathrm{Ca}^{2+}$ measurements were performed as described by Tan et al. (1998a) by flow cytometry. ROS production and intracellular $\mathrm{Ca}^{2+}$ were detected using DCF and Indo-1, respectively. Briefly, the cells were incubated with Indo- 1 and pluronic $\mathrm{F}-127$ for $25 \mathrm{~min}$ at $37^{\circ} \mathrm{C}$; then DCF and pancreatin were added, and cells were incubated for $5 \mathrm{~min}$. Cells were collected and washed once in HEPES buffer supplemented with $2 \%$ dialyzed fetal bovine serum. Washed cells were resuspended in HEPES buffer and kept on ice until flow cytometric analysis. DCF data were collected with the $475 \mathrm{~nm}$ excitation and $525 \mathrm{~nm}$ emission wavelengths and plotted as histograms using the data analysis program CELLQuest (Becton Dickinson, Mountain View, CA). Indo-1 data were collected with two emission wavelengths, $410 \mathrm{~nm}$ (FL32) and $485 \mathrm{~nm}$ (FL4). FL32 and FL4 reflect the fluorescence of Indo-1 with and without bound $\mathrm{Ca}^{2+}$, respectively. The $\mathrm{Ca}^{2+}$ concentration is presented as the ratio of FL32/FL4 (Sagara, 1998; Tan et al., 1998a). Data were analyzed from 10,000 live cells as determined by the lack of propidium iodide fluorescence.

Reverse transcription polymerase chain reaction. Total RNA was prepared from HT22 cells and various tissues of mice and then treated with DNase for $30 \mathrm{~min}$ at $15^{\circ} \mathrm{C}$. Oligonucleotide primers used for the PCR amplification were: D4-1, 5'-CCTTACCCAGCCTCCGGACGA-3', which corresponds to nucleotides 764-784 of the mouse D4 receptor sequence; and D4-2, 5'-GACACGAAGCAAGCCGGACA-3', which is complementary to nucleotides $1018-1037$ of the same sequence. PCR products were electrophoresed on $2 \%$ agarose gels and detected by ethidium bromide.

Western blotting. HT22 cells were collected by scraping in sample buffer. Mouse tissues were homogenized with a Polytron (Kinematica, Basel, Switzerland) for $20 \mathrm{sec}$ in PBS supplemented with a mixture of protease inhibitors (Complete; Roche Molecular Biochemicals, Indianapolis, IN), and then centrifuged at $48,000 \times g$ for $30 \mathrm{~min}$ at $4^{\circ} \mathrm{C}$. The resulting pellets were resuspended in sample buffer (3\% SDS, $1 \%$ glycerol, $0.5 \%$ 2-mercaptoethanol, $0.05 \%$ bromophenol blue, and $80 \mathrm{~mm}$ Tris- $\mathrm{HCl}$ buffer, $\mathrm{pH}$ 6.8, with Complete protease inhibitors). The samples were heated for 3 min in boiling water, fractionated on $12 \%$ polyacrylamide gels, and electroblotted onto membranes. Dopamine receptor D4 affinity purified polyclonal antibody was used as the primary antibody. Immunoreactive bands were detected with the ECL (Amersham Pharmacia Biotech, Arlington Heights, IL) Western blotting detection reagents.

Binding assays. HT22 cells were homogenized with a Polytron for 20 sec in $15 \mathrm{ml}$ of $50 \mathrm{~mm}$ Tris-HCl buffer, $\mathrm{pH}$ 7.4, containing $1 \mathrm{~mm}$ EDTA, and then centrifuged at $48,000 \times g$ for $30 \mathrm{~min}$ at $4^{\circ} \mathrm{C}$. The resulting pellet, which constitutes the membrane fraction, was resuspended in $50 \mathrm{~mm}$ Tris-HCl buffer, $\mathrm{pH}$ 7.4. Binding assays were performed as described by Maroto et al. (1995), with minor modifications. Briefly, $0.5 \mathrm{~nm}\left[{ }^{3} \mathrm{H}\right] \mathrm{spip}-$ erone and the membrane fraction (100-150 $\mu \mathrm{g}$ protein-assay tube) were incubated in $50 \mathrm{~mm}$ Tris-HCl buffer, $\mathrm{pH} 7.4$, containing $125 \mathrm{~mm} \mathrm{NaCl}, 5$ $\mathrm{mm} \mathrm{KCl}, 1 \mathrm{~mm} \mathrm{MgCl} 2,1 \mathrm{~mm} \mathrm{CaCl} 2$, and $0.1 \%$ ascorbic acid for $2 \mathrm{hr}$ at $4^{\circ} \mathrm{C}$. The binding reaction was terminated by rapid filtration through Whatman GF/C filters presoaked in $0.3 \%$ polyethylenimine. The filters were immediately washed three times with $4 \mathrm{ml}$ of ice-cold $50 \mathrm{~mm}$ Tris- $\mathrm{HCl}$ buffer, and radioactivity was measured by liquid scintillation counting. The nonspecific binding was determined in the presence of 100 $\mu \mathrm{M}$ haloperidol. Specific binding was estimated by subtracting nonspecific binding from total binding. Binding assays were done in triplicate. Protein concentration was measured by the Bradford method using bovine serum albumin as the standard.

Statistical analysis. The significance of differences between two groups was assessed by Student's $t$ test. The significance of three or more groups was assessed by the Bonferroni test.

\section{RESULTS}

\section{Effect of dopamine and related compounds on glutamate-induced cell death}

Because there have been suggestions in the literature that catecholamines can protect nerve cells from oxidative stress (Noh et al., 1999; Grünblatt et al., 1999), it was asked whether this phenomenon could be reproduced in a well characterized form of programmed cell death that is initiated by oxidative stress. HT22 cells, which lack ionotropic glutamate receptors, were exposed to increasing concentrations of several catecholamines followed by $2.5 \mathrm{~mm}$ glutamate. Cell viability assays performed $20 \mathrm{hr}$ later showed that glutamate alone kills $>90 \%$ of the cells, whereas dopamine protects HT22 cells in a concentration-dependent manner (Fig. 1A). Apomorphine and apocodeine, two other dopamine receptor ligands, are also protective (Fig. $1 A$ ), whereas epinephrine and norepinephrine are less active. Of the compounds tested, apomorphine was the most effective, followed by apocodeine and dopamine. These compounds did not affect control cell survival, and they also protected cells from higher concentrations of glutamate (data not shown). In addition, apomorphine protects rat cortical neurons lacking ionotropic glutamate receptors from oxidative glutamate toxicity (Fig. 1B).

To confirm the data with the MTT assay and to visually present the dramatic effects of the dopamine analogs on rescuing the cells from glutamate toxicity, some of the conditions in Figure 1 were repeated with the cell viability stain calcein AM. Calcein AM is a fluorogenic esterase substrate that passes through the cell membrane and is hydrolyzed inside the viable cell to the green fluorescent product calcein (Vaughan et al., 1995). Then, live cells were quantitated (Fig. $2 A$ ); photomicrographs of the cells are presented in Figure $2 B$. It is clear that essentially all of the cells were killed by glutamate and that both apocodeine and apomorphine rescue the cells. Quantitation using calcein AM was, within experimental variation, the same as that using the MTT assay (Fig. 1).

Because apomorphine and apocodeine are ligands for dopamine receptors (Van Tol et al., 1991; Seeman and Van Tol, 1994), it is possible that the activation of a dopamine receptor leads to protection. To define the receptor subtype, dopamine receptor antagonists were assayed for their reversal of apomorphine protection in HT22 cells. The protective effects of apomorphine, apocodeine, and dopamine were all inhibited by the D4 antagonists, L745870 and U101958, whereas the weaker protective effects of epinephrine or norepinephrine were not affected by these 
A
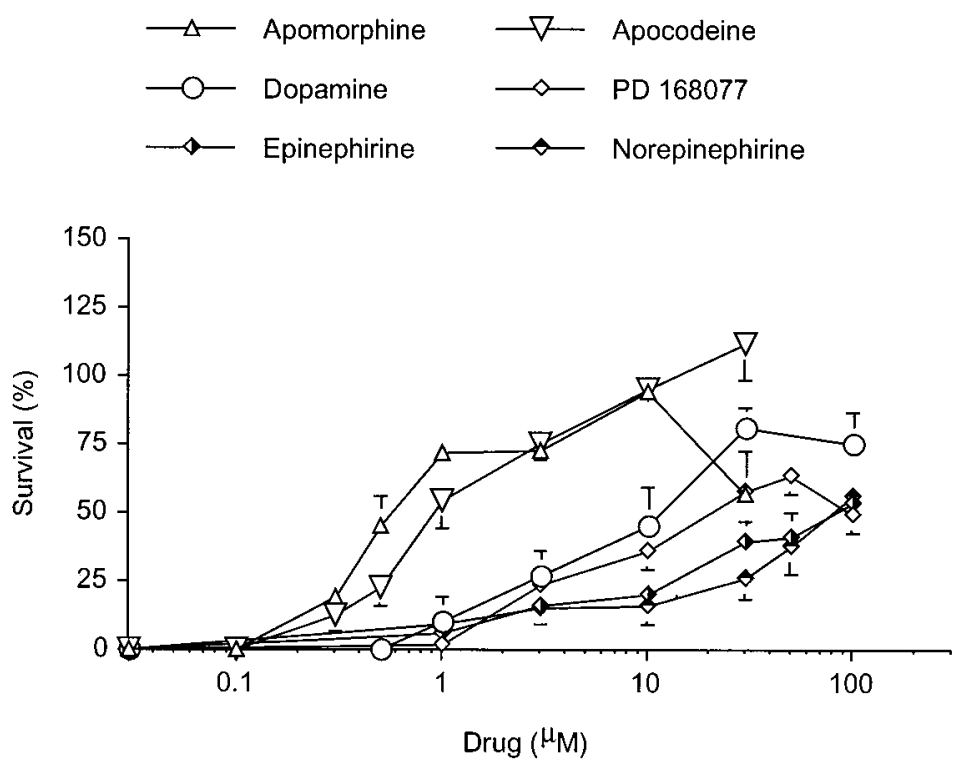

B

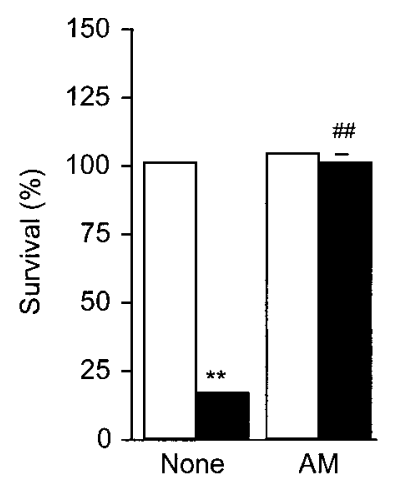

Figure 1. Protective effects of apomorphine and related compounds on glutamate-induced cell death in HT22 cells and primary cortical cells. HT22 ( $A$ ) and 1-d-old primary cortical $(B)$ cells were incubated with various drugs and $2.5 \mathrm{~mm}$ or $5 \mathrm{~mm}$ glutamate, respectively, for 20 hr; then cell survival was measured by the MTT assay. The results are presented as the mean \pm SEM relative percentage survival for three or four independent experiments each done in triplicate. $A M$, Apomorphine $(1 \mu \mathrm{M}) .{ }^{* *} p<0.01$ (vs no glutamate); $\# \# p<0.01$ (vs glutamate alone).

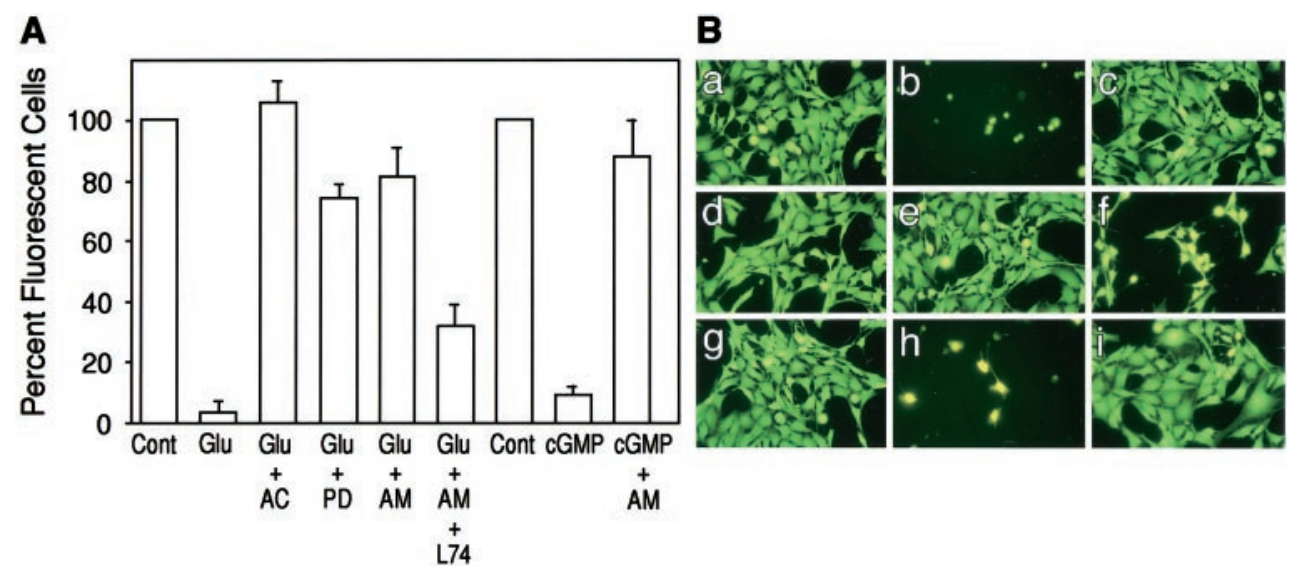

Figure 2. Viability assays using calcein AM. Cells were treated as described below, and viability was determined $20 \mathrm{hr}$ later using calcein AM instead of MTT. $A$, Quantitation of viable cells. Twenty microscopic fields containing between 0 and 80 (control) cells each were scored for viable calcein-positive cells, and the average cells per field in the control (untreated) cultures was given as $100 \%$. The data are presented as the mean cell number relative to control \pm SEM. Cont., Control; Glu, 2.5 mM glutamate; $A C, 10 \mu \mathrm{M}$ apocodeine; $P D, 50 \mu \mathrm{M}$ PD168077; $A M, 1 \mu \mathrm{M}$ apomorphine; L74, $3 \mu \mathrm{M}$ L745870; cGMP, $2.5 \mathrm{~mm}$ pCPT-cGMP. The last three columns were from a separate experiment than the first six. $B$, Photomicrographs of calcein-stained HT22 cell cultures after treatment with the reagents described in $A$ and Figure 1. The conditions are those described in $A . a$, Control; $b$, glutamate; $c$, glutamate plus apocodeine; $d$, glutamate plus PD168077; $e$, glutamate plus apomorphine; $f$, glutamate plus apomorphine plus L745870; $g$, control; $h$, pCPT-cGMP; $i$, pCPT-cGMP plus apomorphine.

antagonists (Fig. 3A). The inhibitory effects of dopamine D4 antagonists were not complete, but we could not use higher concentrations because they were toxic. PD168077, a dopamine D4 receptor agonist, also had a significant protective effect on glutamate-induced cell death, and this protective effect was also antagonized by U101958 (Figs. 1, 3B). The protective effect of the D4 receptor agonist PD168077 and the antagonistic effect of L745870 are also shown in Figure 2 using the calcein AM viability stain. SCH23390, a dopamine D1 receptor antagonist; sulupiride, a dopamine D2 receptor antagonist; and GR103691, a dopamine D3 antagonist, did not antagonize the protective effects of apomorphine or apocodeine, nor did they affect cell survival in the absence of glutamate (data not shown). These data suggest that the dopamine D4 receptor is involved in the protection of cells from oxidative stress by apomorphine.

\section{Antioxidant activity (TEAC)}

It is possible that at least a part of the neuroprotection by apomorphine and related compounds is attributable to their antioxidant activity (Yoshikawa et al., 1994; Grünblatt et al., 1999). To test the antioxidant activities of these compounds, we measured their TEAC values, an index of antioxidant activity in vitro (Table 1). Dopamine had the highest antioxidant activity of the compounds shown in Figure $1 A$, and the antioxidant activity of apomorphine tended to be higher than that of epinephrine or norepinephrine. Apocodeine is a weak antioxidant, although it protects cells as well as apomorphine (Fig. 1). In addition, the D4 agonist PD168077, which is also protective, had no antioxidant activity. As shown in Figure 4, the potencies of the protective effects were correlated with antioxidant activities in SKF38393, 7-hydroxy-dipropylaminotetralin (7-OH DPAT), catecholamines, 


\section{$\begin{array}{lllllll} & \text { None } \quad \square \quad L 45870 \quad \square \quad & \text { U } 101958\end{array}$}

A

Figure 3. Inhibitory effects of D4 antagonists on the neuroprotective effects by apomorphine and related compounds. $A$, HT22 cells were incubated with glutamate $(2.5 \mathrm{~mm})$ and apomorphine $(A M$; $1 \mu \mathrm{M})$, apocodeine $(A C ; 1 \mu \mathrm{M})$, dopamine $(D A ; 30$ $\mu \mathrm{M})$, epinephrine $(E P ; 100 \mu \mathrm{M})$, or norepinephrine $(N E ; 100 \mu \mathrm{M})$ in the presence or absence of the D4 antagonists, L745870 (3 $\mu \mathrm{M})$ or U101958 $(10 \mu \mathrm{M})$, for $20 \mathrm{hr}$; then cell survival was measured by the MTT assay. $B$, HT22 cells were incubated with $2.5 \mathrm{~mm}$ glutamate and $50 \mu \mathrm{M}$ PD168077 in the presence or absence of $10 \mu \mathrm{M}$ U101958 for $20 \mathrm{hr}$; then cell survival was measured by the MTT assay. The results are presented as the mean \pm SEM relative percentage survival for three independent experiments. ${ }^{* *} p<0.01$ (vs control, no glutamate); \#\#p $<0.01$ (vs glutamate alone); $\# p<0.05$ (vs glutamate alone); @p $<0.05$ (vs glutamate in each group). The statistical analysis was performed with the Bonferroni test.

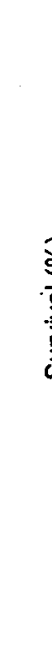

B

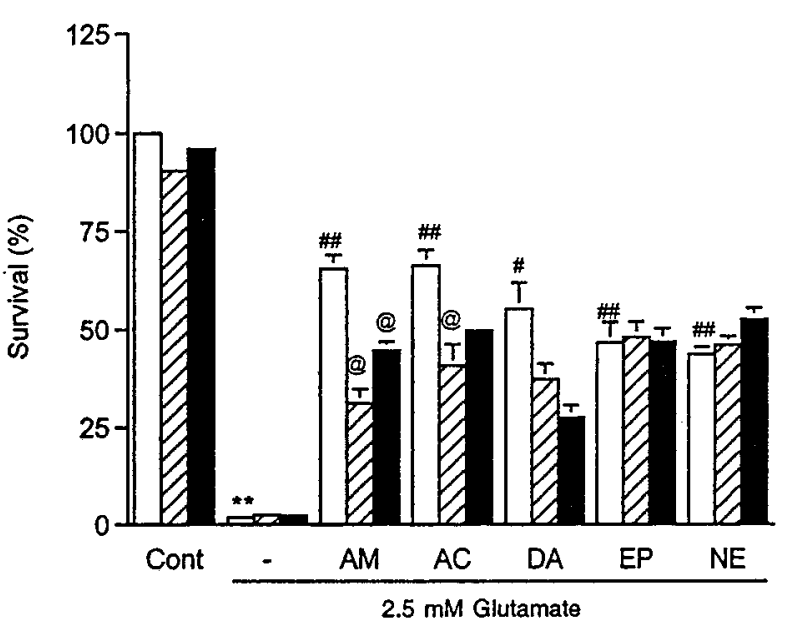

\section{Table 1. TEAC values}

Compounds TEAC (mM)

Apomorphine

$1.70 \pm 0.07$

Apocodeine

PD 168077

$0.74 \pm 0.05$

Dopamine

SKF 38393

7-OH-DPAT

Norepinephirine

Epinephirine

Serotonin

$0.03 \pm 0.14$

$2.40 \pm 0.04$

$4.11 \pm 0.11$

$1.34 \pm 0.10$

$1.54 \pm 0.03$

$1.49 \pm 0.04$

$1.86 \pm 0.07$

$\overline{\text { TEAC values were measured as described in Materials and Methods. The results are }}$ presented as the mean $\pm \mathrm{SE}$ of four independent experiments.

and serotonin. SKF38393 is a D1 agonist and has two phenolic hydroxyl groups. 7-OH DPAT is a D3 agonist and has one phenolic hydroxyl group. In contrast, there is no correlation between antioxidant activity and neuroprotection with apomorphine, apocodeine, or PD168077. It is therefore possible that the first group protects cells by virtue of their antioxidant activity, whereas apomorphine, apocodeine, and PD168077 do so by a different mechanism.

\section{Glutathione, ROS and $\mathrm{Ca}^{2+}$ levels}

Oxidative glutamate toxicity is associated with the depletion of GSH and the elevation of intracellular ROS and $\mathrm{Ca}^{2+}$ (Tan et al., 1998a). To determine where in the programmed cell death pathway apomorphine blocked toxicity, we measured intracellular GSH, ROS, and $\mathrm{Ca}^{2+}$ levels. Dopamine, apomorphine, and apocodeine did not prevent glutamate-induced glutathione depletion (Fig. 5A), showing that this early event in the oxidative stress pathway is not the target for these compounds. In contrast, apomorphine, apocodeine, and dopamine partially inhibited the ROS elevation (Fig. 5B). Dopamine showed the strongest inhibition of ROS production, perhaps because of its powerful antioxidant activity. Finally, all of the drugs inhibited $\mathrm{Ca}^{2+}$ elevation completely (Fig. 5C). Because the influx of $\mathrm{Ca}^{2+}$ is a late event in the oxidative glutamate toxicity death program and because some increase in intracellular $\mathrm{Ca}^{2+}$ is required for maximum ROS

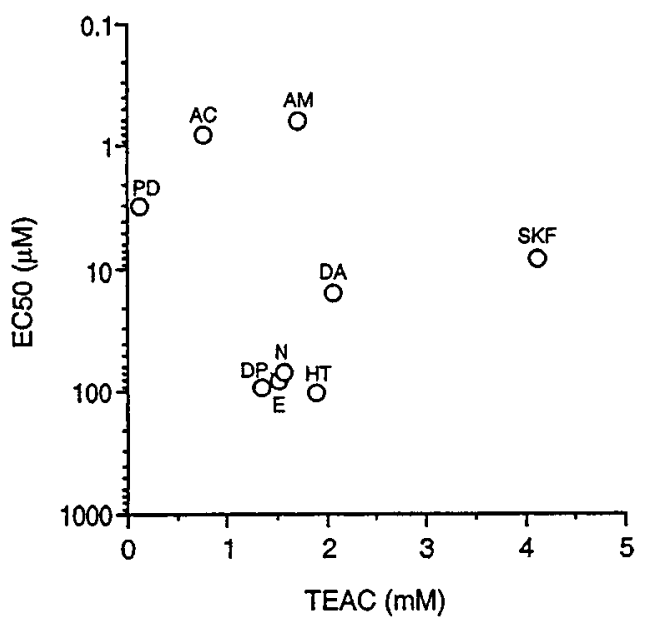

Figure 4. Relationship between the TEAC values and protective effects on glutamate-induced cell death in HT22 cells. TEAC values were obtained from Table $1 . \mathrm{EC}_{50}$ values for suppression of $2.5 \mathrm{~mm}$ glutamateinduced cell death in HT22 cells were calculated from each concentration-response curve and are presented as the mean of three or four independent experiments. $A M$, Apomorphine; $A C$, apocodeine; $P D$, PD168077; DA, dopamine; SKF, SKF38393; DP, 7-hydroxydipropylaminotetralin (7-OH-DPAT); $N$, norepinephrine; $E$, epinephrine; $H T$, serotonin.

production (Tan et al., 1998a), it follows that apomorphine and apocodeine may inhibit cell death by blocking the influx of $\mathrm{Ca}^{2+}$.

\section{cGMP induced $\mathrm{Ca}^{2+}$ influx}

In HT22 cells and cortical neurons, cGMP-dependent $\mathrm{Ca}^{2+}$ channels are opened near the end of the glutamate-induced cell death pathway ( $\mathrm{Li}$ et al., 1997b). To test the possibility that apomorphine and apocodeine modulate these $\mathrm{Ca}^{2+}$ channels, we examined the effects of these compounds on cell death that was caused by the cell permeable cGMP analog, pCPT-cGMP. pCPT-cGMP caused cell death in a dose-dependent manner (data not shown), and $\mathrm{CoCl}_{2}$, a nonselective $\mathrm{Ca}^{2+}$ channel inhibitor, suppressed pCPT-cGMP-induced cell death (Fig. 6A). Apomorphine, apocodeine, PD168077, and dopamine also inhibited pCPT-cGMP-induced cell death (Fig. 6A), showing that they act at a site downstream from cGMP in the cell death 

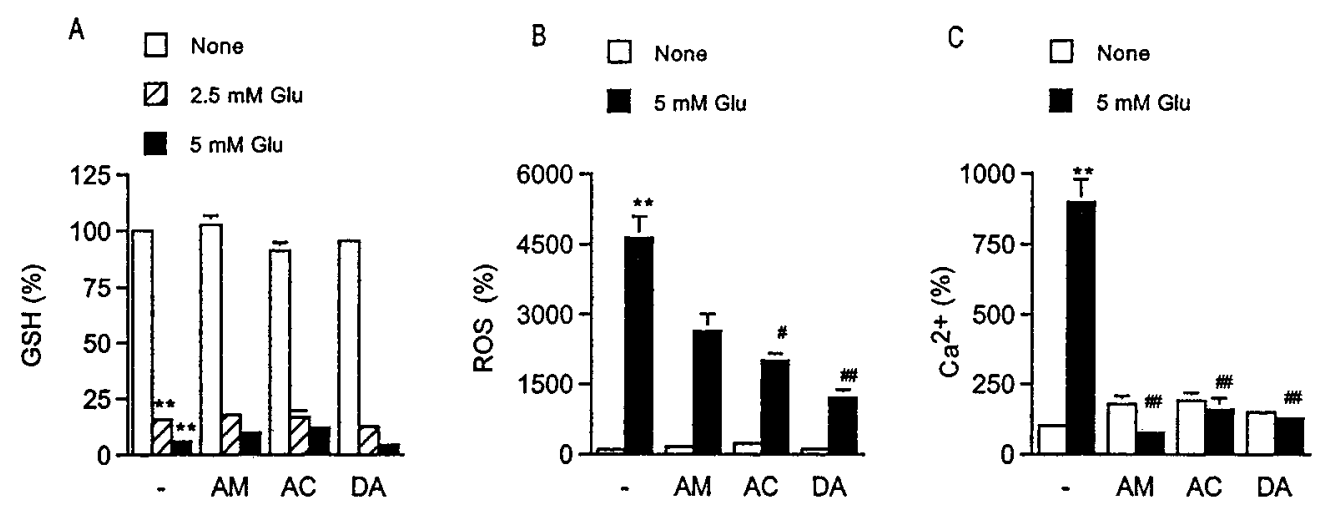

Figure 5. The effects of apomorphine, apocodeine, and dopamine on glutathione $(G S H)$ depletion, reactive oxygen species $(R O S)$ production, and $\mathrm{Ca}{ }^{2+}$ influx by glutamate. Cells were incubated with $2.5 \mathrm{~mm}(G S H)$ or $5 \mathrm{~mm}\left(\mathrm{GSH}, \mathrm{ROS}\right.$, and $\left.\mathrm{Ca}^{2+}\right)$ glutamate and each drug for 8 hr; then GSH, ROS and $\mathrm{Ca}^{2+}$ were measured as described in Materials and Methods. GSH was calculated as nanomoles GSH per milligram of protein and presented as a percentage of the control value. ROS and $\mathrm{Ca}^{2+}$ were calculated as described in Materials and Methods and presented as a percentage of control. All results are presented as the mean \pm SEM for four independent experiments. - , Control; $A M$, apomorphine; $A C$, apocodeine; $D A$, dopamine. ** $p<0.01$ (vs no glutamate); \#p $<0.05$ and \#\#p $<0.01$ (vs $5 \mathrm{~mm} \mathrm{Glu).}$

A

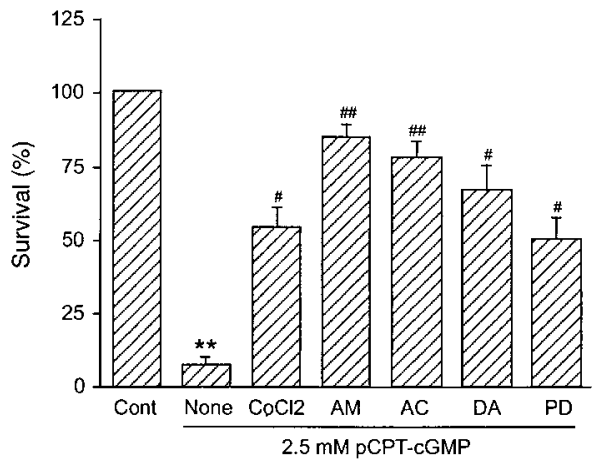

B

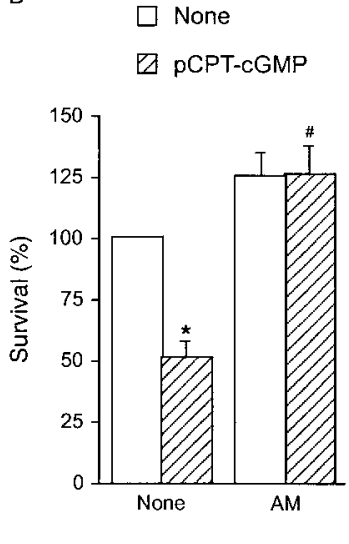

C

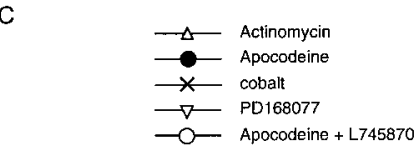

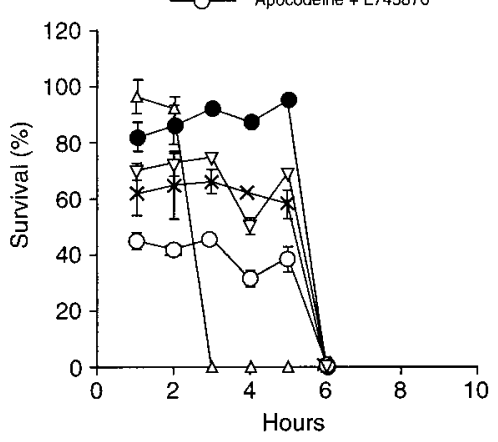

Figure 6. Effects of dopamine receptor ligands on cGMP-induced cell death in HT22 cells and primary cortical neurons. HT22 $(A)$ or 1-d-old cultured cortical $(B)$ cells were incubated with $\mathrm{CoCl}_{2}(50 \mu \mathrm{M})$, apomorphine $(A M ; 1 \mu \mathrm{M})$, apocodeine $(A C ; 1 \mu \mathrm{M})$, dopamine $(D A ; 30 \mu \mathrm{M})$, or PD168077 $(P D$; $50 \mu \mathrm{M})$, followed by the addition of $2.5 \mathrm{~mm}$ pCPT-cGMP. Cell survival was measured by the MTT assay 24 hr later. $C$, Glutamate was added to all samples at 0 time, and $20 \mu \mathrm{M} \mathrm{CoCl}_{2}, 1 \mu \mathrm{M}$ apocodeine, $50 \mu \mathrm{M}$ PD168077, $1 \mu \mathrm{M}$ apocodeine plus $3 \mathrm{~mm} \mathrm{L745870} \mathrm{or} 0.1 \mu \mathrm{g} / \mathrm{ml}$ actinomycin D were added at $2 \mathrm{hr}$ intervals up to $10 \mathrm{hr}$; cell viability was determined after $20 \mathrm{hr}$. The results are presented as the mean \pm SEM relative percentage survival for three independent experiments. ${ }^{*} p<0.05$ and ${ }^{* *} p<0.01$ (vs no glutamate); \#p $<0.05$ and \#\#p $<0.01$ (vs 5 mu glutamate).

pathway. The results with apomorphine using calcein AM are shown in Figure 2. In addition, pCPT-cGMP induced cell death in primary cortical neurons, and these cells were protected by apomorphine (Fig. 6B).

If dopamine and its analogs protect cells primarily via the inhibition of $\mathrm{Ca}^{2+}$ influx, then it would be predicted that they protect cells from glutamate toxicity when added very late in the cell death program in which the $\mathrm{Ca}^{2+}$ influx occurs ( $\mathrm{Li}$ et al., 1997b; Tan et al., 1998a). In addition, this inhibition should parallel the time course for cobalt protection, and both should occur much later than happens with actinomycin D, for the requirement for mRNA synthesis is a very early event (Tan et al., 1998a). To test this possibility, actinomycin $\mathrm{D}, \mathrm{CoCl}_{2}$, the D4 agonist PD168077, apocodeine or apocodeine, plus D4 antagonist L745870 were added to HT22 cells at $2 \mathrm{hr}$ intervals after the addition of glutamate, and cell viability was determined $20 \mathrm{hr}$ later. Figure $6 C$ shows that cells are protected from glutamate when $\mathrm{CoCl}_{2}$, apocodeine, or the D4 agonist is added up to $6 \mathrm{hr}$ after glutamate, whereas the protective effect of apocodeine was partially reversed by L745870. Actinomycin D no longer inhibited toxicity when added after 2 hr. These results show that apocodeine protects cells late in the cell death pathway via the activation of D4 receptors and are consistent with both the cGMP and $\mathrm{Ca}^{2+}$ influx data.

\section{Dopamine receptors in HT22 cells}

The above experiments suggest that HT22 cells have dopamine D4 receptors that mediate the protective response. Three sets of experiments were done to determine whether the HT22 cells express the D4 receptor. D4 receptor mRNA was assayed by reverse transcription polymerase chain reaction (RT-PCR), Western blot experiments were performed to examine protein levels, and ligand binding assays were performed to examine receptor function. In RT-PCR, amplification with D4-1 and D4-2 primers generated a 195 bp cDNA fragment from the HT22 cells, mouse hippocampal RNA, and mouse cortical neuron RNA (Fig. 7A). The corresponding band was not detected in mouse liver or kidney. Similarly, Western blots with an antibody specific to D4 receptors showed that HT22 cells, mouse hippocampal membranes, and mouse cortical neurons have dopamine D4 re- 
Figure 7. The expression of D4 receptors in HT22 cells. A, RT-PCR and Western blot analysis of dopamine D4 receptors in HT22, hippocampal, and cortical cells. DNase-treated total RNA with (+) or without (-) reverse transcription was amplified by PCR. The estimated size of the PCR products was 195 bp. II, Lanes of HT22 cell lysates contained $40 \mu \mathrm{g}$ of protein, and the other lanes contained $20 \mu \mathrm{g}$ of protein. The estimated molecular weight of the D4 receptor is $55 \mathrm{kDa}$ in HT22 and hippocampal neurons and slightly larger in cortical neurons. $B$, Representative Scatchard plot of $\left[{ }^{3} \mathrm{H}\right]$ spiperone binding. The binding assay was performed as described in Materials and Methods by using concentrations of spiperone between $0.5 \mathrm{nM}$ and $2.5 \mu \mathrm{M}$. $C$, Displacement curves for $\left[{ }^{3} \mathrm{H}\right]$ spiperone binding. The binding assay was performed as described in Materials and Methods. The results are presented as the mean \pm SEM of three to five independent experiments. $\mathrm{IC}_{50}$ values are shown in Table 3.
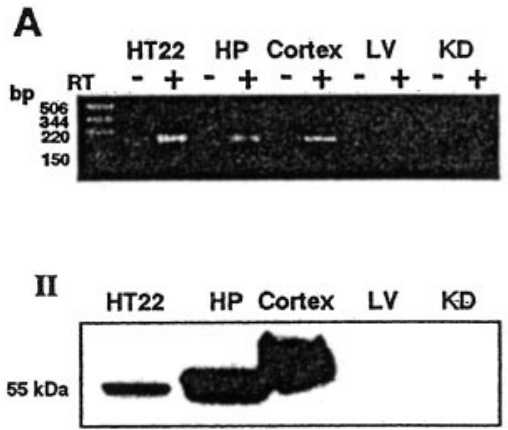
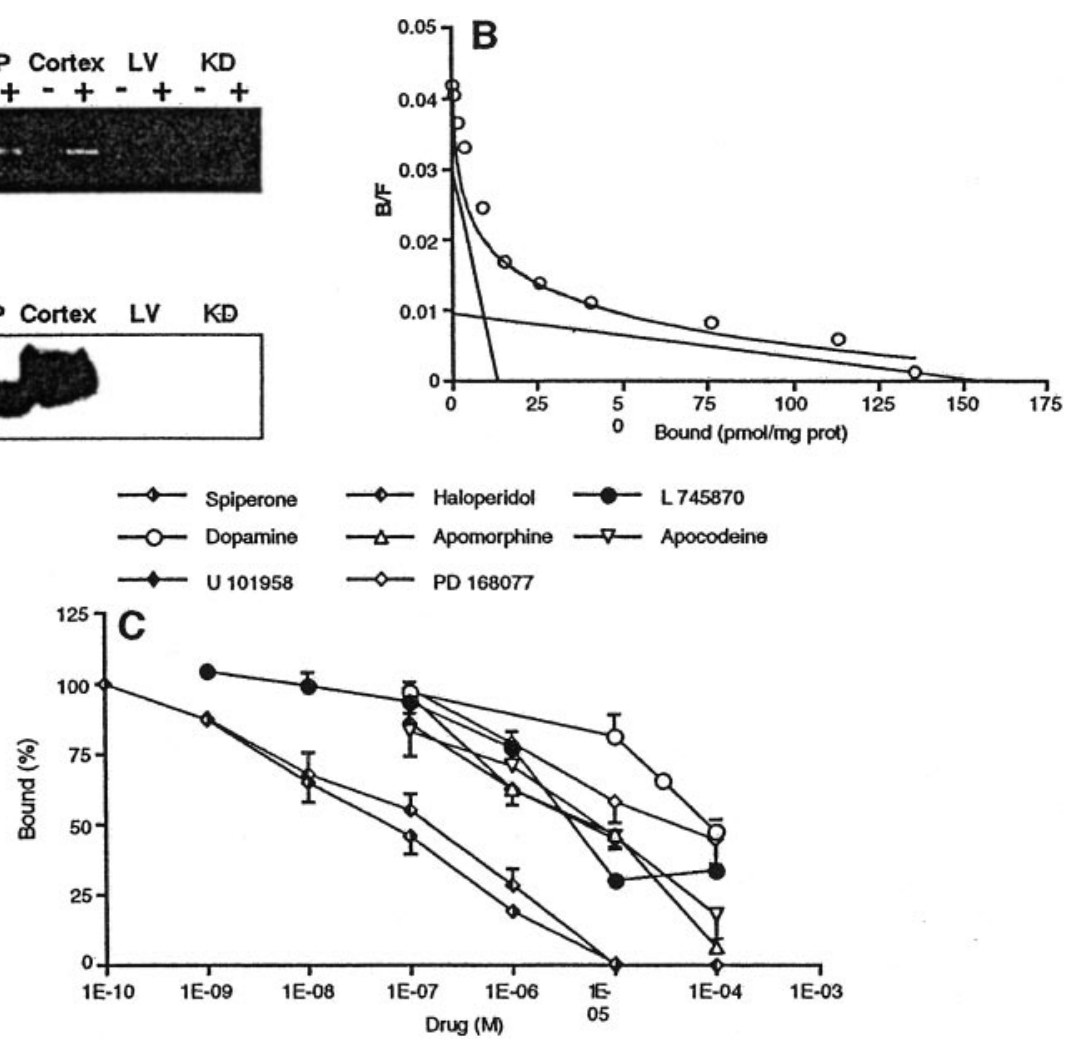

Table 2. $K_{\mathrm{d}}$ and $B_{\max }$ values for $\left[{ }^{3} \mathrm{H}\right]$ spiperone binding

\begin{tabular}{lcr} 
& $K_{\mathrm{d}}(\mathrm{nM})$ & $B_{\max }(\mathrm{pmol} / \mathrm{mg}$ protein $)$ \\
\hline High-affinity sites & $7.21 \pm 0.56$ & $28.88 \pm 13.08$ \\
Low-affinity sites & $446.09 \pm 177.70$ & $174.02 \pm 51.99$
\end{tabular}

$\overline{\text { Scatchard analysis was performed as shown in Figure 7. The results are presented as }}$ the mean $\pm \mathrm{SE}$ of four independent experiments.

ceptors (Fig. 7AII). In the liver and kidney, this band was not observed. The molecular weight of these proteins was estimated at $55 \mathrm{kDa}$. These data show that HT22 cells and the tissue from which they were derived, mouse hippocampus, both express D4 receptors.

To further characterize the dopamine D4 receptors in HT22 cells, we performed binding assays. Scatchard plots for the dopamine receptor antagonist $\left[{ }^{3} \mathrm{H}\right]$ spiperone binding to HT22 cells are curvilinear (Fig. $7 C$ ), fitting a two site binding model. As shown in Table 2, the $K_{\mathrm{d}}$ values for high- and low-affinity sites are $7.21 \pm 0.56 \mathrm{~nm}$ and $466 \pm 177 \mathrm{~nm}$, respectively, and the $B_{\max }$ values are $28.88 \pm 13.08 \mathrm{pmol} / \mathrm{mg}$ protein and $174.02 \pm 51.99$ $\mathrm{pmol} / \mathrm{mg}$ protein, respectively. Displacement experiments showed that various nonselective and D4-selective ligands inhibited $\left[{ }^{3} \mathrm{H}\right]$ spiperone binding (Fig. $7 C$, Table 3 ). The most effective displacing agent was spiperone, followed by haloperidol. The $\mathrm{IC}_{50}$ value for apomorphine was almost the same as that of apocodeine. The displacing potency of dopamine was the same or weaker than that of the D4 ligands, U101958, L745870, and PD168077.

\section{DISCUSSION}

The above data show that the activation of dopamine D4 receptors can play a role in the protection of nerve cells from oxidative stress-induced cell death. This conclusion is based on the follow-
Table 3. $\mathrm{IC}_{50}$ values for $\left[{ }^{3} \mathrm{H}\right]$ spiperone binding

\begin{tabular}{lc} 
Ligand & $\mathrm{IC}_{50}(\mu \mathrm{M})$ \\
\hline Spiperone & $0.11 \pm 0.03$ \\
Haloperidol & $0.31 \pm 0.15$ \\
L 745870 & $3.06 \pm 1.21$ \\
U 101958 & $7.66 \pm 3.33$ \\
PD 168077 & $26.10 \pm 3.12$ \\
Apomorphine & $5.96 \pm 2.15$ \\
Apocodeine & $6.41 \pm 1.49$ \\
Dopamine & $77.82 \pm 10.10$
\end{tabular}

$\mathrm{IC}_{50}$ values were calculated from each displacement curve. The results are presented as the mean $\pm \mathrm{SE}$ of three to five independent experiments.

ing observations. (1) Apomorphine, apocodeine, and dopamine all protect the HT22 mouse hippocampal nerve cell line and rat cortical neurons from oxidative stress induced by oxidative glutamate toxicity (Figs. 1, 2). (2) This protective effect is reversed by D4 antagonists, but not by D1, D2, or D3 antagonists (Fig. 3). (3) A selective D4 agonist, PD168077, also protects neurons from oxidative stress (Figs. 1, 2). (4) The protective effects of the D4 agonists cannot be explained by their inherent antioxidant properties alone (Fig. 4, Table 1). (5) HT22 cells express the mRNA, protein, and physiological binding properties of D4 dopamine receptors (Fig. 7, Tables 2, 3).

It has been suggested that the neuroprotective effects of catecholamines, including dopamine, epinephrine, and norepinephrine are attributable to their antioxidant activities and are not receptor-mediated (Grünblatt et al., 1999; Noh et al., 1999). In the above experiments, it is indeed shown that many catecholamines have antioxidant activity, and that antioxidant activity may be part of the neuroprotective effect of apomorphine. However, D4 receptor mechanisms are more predominant than 
antioxidant activities because the protective effect of apomorphine, which is a relatively good antioxidant, is the same as that of apocodeine, which is a relatively poor antioxidant, and stronger than catecholamines, which are also good antioxidants (Table 1). In addition, the D4 agonist PD168077 has no antioxidant activity but is very protective.

It is also known that exogenous dopamine can be neurotoxic. Dopamine is degraded to hydrogen peroxide and dihydroxyphenylacetaldehyde by monoamine oxidase or spontaneously oxidizes to form quinones, semiquinones, and again hydrogen peroxide. Several of these products can lead to the generation of reactive oxygen species such as hydroxyl radicals. Therefore, there has been considerable interest in the potential role of dopamine in CNS ischemia and trauma. Indeed it has been established in several in vivo models that dopamine is involved in the cell death pathway. For example, when brain lesions are caused by malonate or 3-nitropropionic acid, two reagents that inhibit energy metabolism, the experimental reduction of dopamine greatly diminishes the extent of damage (Reynolds et al., 1998; Ferger et al., 1999). These results are not, however, at odds with ours because the nature of the insults is quite different (energy deprivation versus oxidative stress) and the levels of multiple toxic agents released from both dying nerve and activated glia are likely to be much higher in severely traumatized CNS tissue than in oxidatively stressed nerve cell cultures. The significance of the dopamine D4 receptor activation may be that it protects cells from gradual changes in low level oxidative stress that occur in mild pathological insults and aging.

The mouse dopamine D4 receptor mRNA is found in the hippocampus and other brain regions, and also in some peripheral tissues such as the adrenal gland and the testes (Van Tol et al., 1991). It is not found in other peripheral tissues, including liver and kidney. Our RT-PCR data from mouse tissues (Fig. 7A) are consistent with the published data with respect to the regional specificity of this receptor and size of its mRNA. They also demonstrate that HT22 cells express dopamine D4 receptor mRNA. The mouse D4 receptor has 387 amino acids with a calculated molecular weight of 41,468 (Fishburn et al., 1995; Suzuki et al., 1995). This molecular weight is smaller than the estimated molecular weight from the western blots in this manuscript but is consistent with the apparent molecular weight of the dopamine D4 receptor published by others, probably because of glycosylation (Suzuki et al., 1995; Lanau et al., 1997).

Binding assays also show that dopamine D4 receptors are expressed in the HT22 cells and that apomorphine and apocodeine bind the receptors with higher affinities than dopamine. These data agree with those that show that although apomorphine is a nonselective dopamine receptor agonist, its affinity for D4 receptors is severalfold higher than that of dopamine (Seeman and Van Tol, 1994). In addition, the affinities of apomorphine and apocodeine for the D4 dopamine receptor in HT22 cells are the same as the dopamine D4 antagonist U101958 and higher than the D4 agonist PD168077. These data show that apomorphine, apocodeine, and dopamine can all act as dopamine D4 agonists.

A great deal is understood about the programmed cell death pathway initiated by glutamate in HT22 cells and primary cortical neurons (Maher and Davis, 1996; Murphy et al., 1989; Li et al., 1997a,b; Tan et al., 1998a,b). This knowledge makes it possible to determine at which point in the pathway the drug-induced inhibition of cell death occurs. There are two features of this pathway that are relevant to apomorphine protection. First, maximum ROS production requires the influx of extracellular $\mathrm{Ca}^{2+}(\mathrm{Li}$ et al., 1997b; Tan et al., 1998a). Second, the influx of $\mathrm{Ca}^{2+}$ is initiated by an accumulation of intracellular cGMP via the activation of soluble guanylate cyclase (Li et al., 1997b). The data presented here show that apomorphine, apocodeine, and dopamine inhibit the cell death program at the level of cGMP-gated $\mathrm{Ca}^{2+}$ influx. In the presence of these compounds, ROS are elevated but do not reach their maximum levels (Fig. 5). This result is identical to that observed when the synthesis of cGMP is blocked, preventing $\mathrm{Ca}^{2+}$ influx, or when the $\mathrm{Ca}^{2+}$ channel is blocked by cobalt (Li et al., 1997b; Tan et al., 1998a). The data are therefore consistent with the block being associated with $\mathrm{Ca}^{2+}$ influx, a conclusion confirmed by $\mathrm{Ca}^{2+}$ imaging (Fig. 5). To more precisely localize the site of protection, it was asked whether apomorphine inhibits cell death that is caused by elevated intracellular cGMP. The elevation of cGMP and the resultant opening of the cGMP-gated $\mathrm{Ca}^{2+}$ channels are both necessary and sufficient to cause cell death in oxidative glutamate toxicity ( $\mathrm{Li}$ et al., 1997b). Figure 6 shows that apomorphine, apocodeine, and dopamine all protect cells from elevated cGMP with a time of action indistinguishable from that of cobalt. Therefore, it is most likely that the activation of D4 receptors inhibits a step downstream of cGMP, probably at the $\mathrm{Ca}^{2+}$ channel. Indeed, it has been suggested that the activation of dopamine D4 receptors reduces $\mathrm{Ca}^{2+}$ currents (Sokoloff and Schwartz, 1995). The present study shows that apomorphine, apocodeine, and dopamine protect cells from oxidative stress-induced cell death by the inhibition of $\mathrm{Ca}^{2+}$ channels through the activation of dopamine D4 receptors.

\section{REFERENCES}

Ferger B, Eberhardt O, Teismann P, de Groote C, Schulz JB (1999) Malonate-induced generation of reactive oxygen species in rat striatum depends on dopamine release but not on NMDA receptor activation. J Neurochem 73:1329-1332.

Fishburn CS, Carmon S, Fuchs S (1995) Molecular cloning and characterization of the gene encoding the murine D4 dopamine receptor. FEBS Lett 361:215-219.

Grünblatt E, Mandel S, Gassen M, Youdim MBH (1999) Potent neuroprotective and antioxidant activity of apomorphine in MPTP and 6-hydroxydopamine induced neurotoxicity. J Neural Transm [Suppl] 55:57-70.

Lanau F, Brockhans M, Pink JRL, Franchet C, Wildet-Perinie D, Goepfert C, Probst A, Hartman DS (1997) Development and characterization of antibodies against the $\mathrm{N}$ terminus of the human dopamine D4 receptor. J Neurochem 69:2169-2178.

Li Y, Maher P, Schubert D (1997a) A role for 12-lipoxygenase in nerve cell death caused by glutathione depletion. Neuron 19:453-463.

Li Y, Maher P, Schubert D (1997b) Requirement for cGMP in nerve cell death caused by glutathione depletion. J Cell Biol 139:1317-1324.

Liu Y, Peterson DA, Kimura H, Schubert D (1997) Mechanism of cellular 3-(4,5-dimethylthiazol-2-yl)-2,5-diphenyltetrazolium bromide (MTT) reduction. J Neurochem 69:581-593.

Maher P, Davis J (1996) The role of monoamine metabolism in oxidative glutamate toxicity. J Neurosci 16:6394-6401.

Maher P, Schubert D (2000) Signaling by reactive oxygen species in the nervous system. Cell Mol Life Sci 57:1287-1305.

Maroto R, Lopez MG, Del Valle M, Naranjo JR, Mellstrom B, Garcia AG (1995) Expression of the bovine striatal D2 receptor, but not the D1 receptor, in bovine adrenal medulla. Mol Pharmacol 47:40-50.

Miller NJ, Rice-Evans CA, Davies MJ, Gopinathan V, Miller A (1993) A novel method for measuring antioxidant capacity and its application to monitoring the antioxidant status in premature neonates. Clin Sci 84:407-4122.

Murphy TH, Miyamoto M, Sastre A, Schnaar RL, Coyle JT (1989) Glutamate toxicity in a neuronal cell line involves inhibition of cystine transport leading to oxidative stress. Neuron 2:1547-1558.

Noh JS, Kim EY, Kang JS, Kim HR, Oh YJ, Gwag BJ (1999) Neurotoxic and neuroprotective actions of catecholamines in cortical neurons. Exp Neurol 159:217-224.

Reynolds DS, Carter RJ, Morton AJ (1998) Dopamine modulates the susceptibility of striatal neurons to 3-nitropropionic acid in the rat model of Huntington's disease. J Neurosci 18:10116-10127.

Sagara Y (1998) Induction of reactive oxygen species in neurons by haloperidol. J Neurochem 71:1002-1012. 
Sagara Y, Schubert D (1998) The activation of metabotropic glutamate receptors protects nerve cells from oxidative stress. J Neurosci 18:6662-6671.

Sam EE, Verbeke N (1995) Free radical scavenging properties of apomorphine enantiomers and dopamine: possible implication in their mechanism of action in Parkinsonism. J Neural Transm 10:115-127.

Seeman P, Van Tol HHM (1994) Dopamine receptor pharmacology. Trends Pharmacol Sci 15:264-270.

Sethy VH, Wu H, Oosveen JA, Hall ED (1997) Neuroprotective effects of the dopamine agonists pramipexole and bromocriptine in 3-acetylpyridine-treated rats. Brain Res 754:181-186.

Sokoloff P, Schwartz JC (1995) Novel dopamine receptors half a decade later. Trends Pharmacol Sci 16:270-275.

Suzuki T, Kobayashi K, Nagatsu T (1995) Genomic structure and tissue distribution of the mouse dopamine D4 receptor. Neurosci Lett 199:69-72.

Takashima H, Tsujihara M, Kishikawa M, Freed WJ (1999) Bromocrip- tine protects dopaminergic neurons from levodopa-induced toxicity by stimulating D2 receptors. Exp Neurol 159:98-104.

Tan S, Sagara Y, Liu Y, Maher P, Schubert D (1998a) The regulation of reactive oxygen species production during programmed cell death. J Cell Biol 141:1423-1432.

Tan S, Wood M, Maher P (1998b) Oxidative stress induces a form of programmed cell death with characteristics of both apoptosis and necrosis in neuronal cells. J Neurochem 71:95-105.

Van Tol HHM, Bunzow JR, Guan H-C, Sunahara RK, Seeman P, Niznik HB, Civelli O (1991) Cloning of the gene for a human dopamine D4 receptor with high affinity for the antipsychotic clozapine. Nature 350:610-614.

Vaughan PJ, Pike CJ, Cotman CW, Cunningham DD (1995) Thrombin receptor activation protects neurons and astrocytes from cell death produced by environmental insults. J Neurosci 15:5389-5401.

Yoshikawa T, Minamiyama Y, Naito Y, Kondo M (1994) Antioxidant properties of bromocriptine, a dopamine agonist. J Neurochem 62 $1034-1038$. 